\title{
EVIDENCE FOR FMRF-AMIDE AS A NEUROTRANSMITTER IN THE GILL OF APLYSIA CALIFORNICA ${ }^{1}$
}

\author{
SAM WEISS, ${ }^{* 2}$ JEFF I. GOLDBERG, $\ddagger$ KULDIP S. CHOHAN, $\ddagger$ WILLIAM K. STELL, \\ GEORGE I. DRUMMOND, ${ }^{*, 3}$ AND KEN LUKOWIAK $\ddagger$ \\ Departments of *Chemistry, and $\ddagger$ Anatomy and Medical Physiology, University of Calgary, Calgary, Alberta, Canada, T2N 4 N1
}

Received September 23, 1983; Revised February 13, 1984; Accepted February 21, 1984

\begin{abstract}
In Aplysia californica, multiple regulatory mechanisms are involved in the actions of neurotransmitters on the gill. Neurotransmitter receptors and adenylate cyclase were examined in a particulate fraction of gill homogenates. The neuropeptide FMRF-amide stimulated enzyme activity 7-to 8-fold ( $\mathrm{EC}_{50}, 1 \mu \mathrm{M}$ ) via receptors that were pharmacologically distinct from those for dopamine and serotonin. FMRF-amide augmented cyclic AMP levels in slices of gill tissue with a time course similar to that for adenylate cyclase activation. Increases in cyclic AMP levels produced by the neuropeptide were potentiated by the phosphodiesterase inhibitor theophylline. Physiological responses to neuropeptides and cyclic AMP analogues were examined in a perfused, isolated gill preparation. Phasic contractions evoked by FMRF-amide $\left(\mathrm{EC}_{50}, 0.1 \mu \mathrm{M}\right)$ were mimicked by membrane-permeable analogues of cyclic AMP. Comparison of FMRF-amide effects on adenylate cyclase and gill behavior suggests an association between cyclic AMP and phasic contractions. In addition, FMRF-amidelike immunoreactivity, detected by antisera raised against the neuropeptide, was found in nerve fibers innervating the gill. These findings indicate that in Aplysia, FMRF-amide or a closely related peptide neurotransmitter may be involved in the physiological regulation of gill behavior.
\end{abstract}

The gill of the marine mollusc Aplysia californica is an external respiratory organ whose adaptive behavior appears to be mediated by an interaction of the central and peripheral nervous systems (Lukowiak and Peretz, 1977). Previous studies have provided evidence for dopamine and serotonin innervation of the gill musculature (Peretz and Estes, 1974) and have suggested possible roles for these putative neurotransmitters in gill function (Ruben et al., 1979). Recent reports have demonstrated the ability of neuropeptides to modulate the activity of central neurons and adaptive gill behavior in Aplysia (Moore et al., 1981; Lukowiak et al., 1982). The neuropeptide FMRFamide (Phe-Met-Arg-Phe- $\mathrm{NH}_{2}$ ), first discovered in the ganglion of the venus clam Macrocallista nimbosa (Price and Greenberg, 1977), has been suggested as a regulator of neurons (Cottrell, 1982; Grayton, 1982) and also of peripheral tissues (Price and Greenberg, 1980) of vertebrates and invertebrates.

${ }^{1}$ This work has been supported by the Medical Research Council of Canada and the Alberta Heritage Foundation for Medical Research. S. W. and J. I. G. are recipients of Alberta Heritage Foundation for Medical Research graduate studentships. We are extremely grateful to Dr. G. J. Dockray, Physiological Laboratory, University of Liverpool, for providing antiserum (no. L-135) to FMRF-amide.

${ }^{2}$ To whom correspondence should be directed, at his present address: Centre CNRS-INSERM de Pharmacologie-Endocrinologie, B.P. 505534033 Montpellier, Cedex, France.

${ }^{3}$ George Ira Drummond, Killan Memorial Professor of Chemistry and Medical Biochemistry, University of Calgary, passed away on May 19,1984 . His dedication and integrity has and will continue to serve as an inspiration to us all.
In Aplysia, we have found that FMRF-amide superfusion over the abdominal ganglion increased the amplitude of the gill withdrawal reflex and prevented its habituation (Voshart and Lukowiak, 1982). In addition, FMRF-amide inlibited spontaneous and induced contractions of the anterior gizzard (Austin et al., 1983), suggesting a putative regulatory role for the neuropeptide in both central and peripheral tissues. In this paper we describe several lines of evidence that suggest that FMRF-amide or a closely related peptide is a neurotransmitter in the gill of Aplysia. Furthermore, the findings of our laboratory and others (Morris et al., 1982) provide evidence for the hypothesis that a family of neuropeptides, with sequence homology, may be pivotal modulators of both the central nervous system and peripheral tissues in Aplysia.

\section{Materials and Methods}

$\left[2,8-{ }^{3} \mathrm{H}\right]$ Adenosine $3^{\prime}, 5^{\prime}$-cyclic phosphate $(30 \mathrm{Ci} / \mathrm{mmol})$ and $\left[\alpha{ }^{32} \mathrm{P}\right]$ ATP $(20$ to $30 \mathrm{Ci} / \mathrm{mmol}$ ) were purchased from New England Nuclear Corp. (Boston, MA). Aqueous counting scintillant (ACS) and cyclic AMP assay kits were obtained from Amersham Searle (Arlington Heights, IL). ATP, GTP, cyclic AMP, creatine phosphokinase (type I, rabbit muscle), creatine phosphate, dithiothreitol (DTT), 3-isobutyl-1methylxanthine (IBMX), bovine serum albumin, imidazole, phenylalanine, methionine, and arginine were purchased from Sigma Chemical Co. (St. Louis, MO). Other agents were obtained from the following sources: 8-benzylthio-cAMP from ICN (Plainview, NY); dopamine $\mathrm{HCl}$ and serotonin creatine sulfate from Nutritional Biochemical Corp. (Cleveland, $\mathrm{OH}$ ); 8-parachlorophenylthio-cAMP and $\mathrm{N}$-2,6-dibutyrylcGMP from Boehringer Mannheim (Dorval, Quebec, Canada); methionine enkephalin from Calbiochem Boehring (San Diego, CA); PheMet-Arg-Phe-NH $\mathrm{N}_{2}$, Tyr-Phe-Met-Arg-Phe-NH $\mathrm{N}_{2}$, and Tyr-Gly-Gly- 
Phe-Met-Arg-Phe- $\mathrm{NH}_{2}$ from Peninsula Laboratories, Inc. (San Carlos, $\mathrm{CA})$. Chlorpromazine $(\mathrm{HCl})$ was obtained from Dr. S. Roth, University of Calgary (Calgary, Alberta, Canada).

Isolated gill preparation. Physiological experiments were performed using $A$. californica weighing between 80 and $250 \mathrm{gm}$. The animals were obtained primarily from Pacific Biomarine, Inc. (Venice, CA) or Sea Life Supply (Sand City, CA). Animals were maintained in gravelfiltered aquaria containing artificial sea water (ASW; Aquarium Systems, Mentor, $\mathrm{OH}$ ) which was kept at 15 to $16^{\circ} \mathrm{C}$ and at a specific gravity of 1.023 to 1.025 .

The experimental preparation (Ruben and Lukowiak, 1979), consisting of the siphon, mantle, and gill isolated from the abdominal ganglion, was pinned to the Sylgard (Dow Corning Corp., Midland, MI) base of a Lucite dish. The dish was filled with sea water. The preparation was positioned dorsal side down and pinned through the mantle, through the body wall near the heart, near the opaline gland, and again near the siphon. Opaline and gameolytic glands were removed. The remaining visceral organs did not obstruct experimental manipulation and, therefore, were left intact.

At this point, for biochemical experiments, the entire gill was removed from the semi-intact preparation by severing the afferent vein as well as the efferent vein and muscular connections to the body wall. The gill was frozen $\left(-80^{\circ} \mathrm{C}\right)$ for subsequent preparation of the partic- ulate fraction. For examination of cAMP accumulation, 1- to 2-mm tissue cross-sections were prepared and were placed in ASW for $1 \mathrm{hr}$ at 0 to $4^{\circ} \mathrm{C}$.

For physiological experiments, the dish containing the semi-intact preparation was transferred to the experimental set-up. Gill perfusion was accomplished through a glass cannula inserted into the afferent branchial vessel. Perfusion fluid was delivered by gravity flow $(5 \mathrm{ml} /$ min) into the gill from a drip bottle and tubing system which permitted cooling to $15^{\circ} \mathrm{C}$. A diagram of the experimental preparation is presented in Figure 1. The entire preparation was maintained at $15^{\circ} \mathrm{C}$ by a cooling system. The control perfusate was ASW. Experimental solutions were prepared in ASW. Such solutions were prepared immediately prior to use to avoid oxidation of labile substances (especially dopamine (DA)). An interval of $1 \mathrm{hr}$, and in certain cases $30 \mathrm{~min}$, separated administration of experimental agents. After steady perfusion was attained, a suture was tied to a single pinnule and connected to a Grass isotonic force transducer type FT03C. Movements detected by the force transducer were amplified by Grass EEG type 7P511 and low level DC type 7P122 amplifiers and were recorded on a Grass oscillograph.

Preparation of gill particulate fraction. For biochemical experiments, gills were obtained from semi-intact preparations that had not been pharmacologically treated. Gills were removed by cutting the afferent and efferent veins and muscular connections to the body wall, blotted,

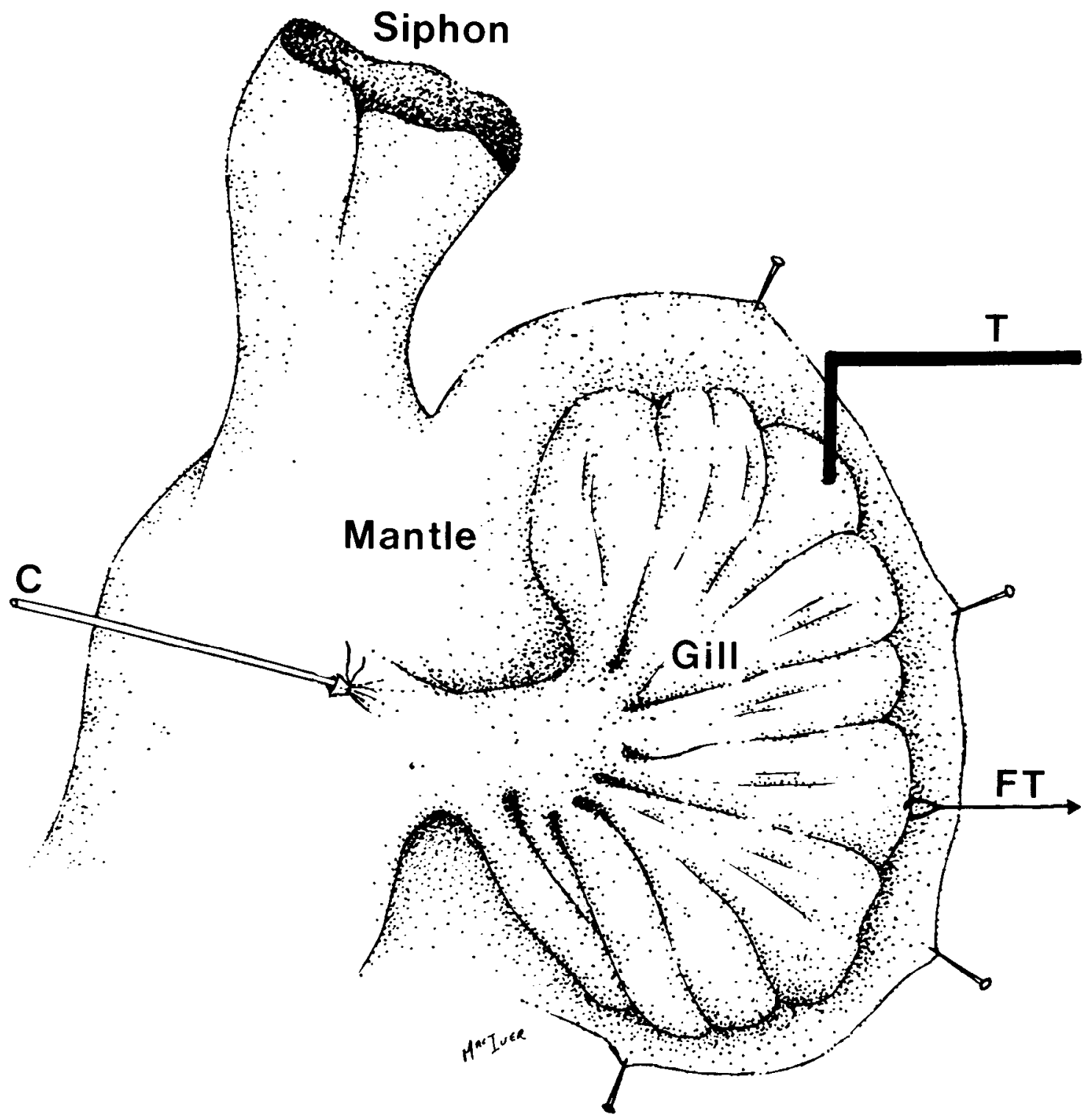

Figure 1. Diagram of the experimental preparation. The semi-intact A. californica preparation consisted of the siphon, mantle, and gill isolated from the abdominal ganglion (CNS). Perfusion $(5 \mathrm{ml} / \mathrm{min})$ was through a glass cannula $(C)$ inserted into the afferent sinus of the branchial vein. The gill was connected to an isotonic tension transducer $(F T)$. Effluent ASW was removed by suction. $T$, Tapper. 
weighed and immediately frozen at $-80^{\circ} \mathrm{C}$ until used. Frozen tissue was cut into pieces, suspended in $10 \mathrm{vol}$ of $0.25 \mathrm{M}$ sucrose, $20 \mathrm{~mm}$ 'Tris- $\mathrm{HCl}$, $1 \mathrm{mM} \mathrm{D}^{\prime} \mathrm{TT}$ ( $\mathrm{pH}$ 7.5) (buffer A), and homogenized in a Potter-Elvehjem homogenizer with a Teflon pestle for 100 passes. The homogenate was passed through a $100-\mu \mathrm{m}$ nylon filter under light suction to remove connective tissue and was centrifuged at $38,000 \times g$ for $20 \mathrm{~min}$. The pellet was washed twice by suspending in buffer followed by centrifugation; it was finally suspended in $10 \mathrm{vol}$ of buffer (based on initial tissue weight) to a protein concentration of 3 to $4 \mathrm{mg} / \mathrm{ml}$. The preparation was divided into aliquots sufficient for a single experiment which were stored at $-80^{\circ} \mathrm{C}$ (for not longer than 1 week before use).

Assay of adenylate cyclase. The standard reaction mixture contained $40 \mathrm{~mm}$ Tris- $\mathrm{HCl}(\mathrm{pH} 7.5), 8 \mathrm{mM} \mathrm{MgSO}_{4}, 1 \mathrm{mM}$ cAMP, $1.0 \mathrm{~mm}$ IBMX, $10 \mathrm{mM}$ creatine phosphate, $530 \mu \mathrm{g} / \mathrm{ml}$ of creatine phosphokinase, 90 to $120 \mu \mathrm{g}$ of gill particulate preparation $\left(100 \mu \mathrm{M}\right.$ GTP), $0.5 \mathrm{mM}\left[{ }^{32} \mathrm{P}\right] \mathrm{ATP}$ $(40 \mathrm{dpm} / \mathrm{pmol})$, and test substances in a final volume of $0.15 \mathrm{ml}$. The reaction was initiated by the addition of $30 \mu \mathrm{l}$ of membrane suspension after a 1 -min prior incubation at $25^{\circ} \mathrm{C}$. The incubation was conducted with constant shaking at $25^{\circ} \mathrm{C}$ for $10 \mathrm{~min}$ and was terminated by the addition of $0.1 \mathrm{ml}$ of "stop" reagent containing $2 \%$ sodium dodecyl sulfate, $40 \mathrm{mM}$ ATP, and $1.4 \mathrm{mM}$ cAMP, $\mathrm{pH} 7.5$. To monitor product recovery, $50 \mu \mathrm{l}$ of $\left[{ }^{3} \mathrm{H}\right] \mathrm{cAMP}\left(1 \times 10^{6} \mathrm{dpm} / \mathrm{ml}\right)$ were added to the mixture. The $\left[{ }^{32} \mathrm{P}\right] \mathrm{cAMP}$ formed was isolated and quantitated by the method of Salomon et al. (1974). All assays were performed in duplicate. Specific activity is expressed as picomoles of cAMP formed per minute per milligram.

cAMP accumulation assay. Freshly prepared 1- to 2-mm cross-sections of Aplysia gill were used in all experiments. All test agents were made up at the indicated concentrations in ASW immediately before use and were transferred to $10-\mathrm{ml}$ beakers which were incubated at the indicated temperatures $\left(15\right.$ to $\left.30^{\circ} \mathrm{C}\right)$ for $1 \mathrm{~min}$. Reactions were initiated by addition of the gill slice, were conducted with constant shaking for $5 \mathrm{~min}$ (or other times, depending on the experimental protocol), and were terminated by immersion of the tissue in liquid nitrogen. cAMP was determined according to the method of Brown et al. (1971) using the commercial cAMP assay kit. All assays were performed in duplicate.
Activity is expressed as picomoles of cAMP formed per milligram of protein.

Protein determination. Protein concentration was determined by the method of Lowry et al. (1951) using bovine serum albumin as the standard.

\section{Results}

Neuropeptide-sensitive adenylate cyclase. Recently, attention has been directed toward the examination of neuropeptides and their regulation of physiological function. Some of these effects have been suggested to occur via modulation of intracellular cyclic nucleotide levels through cell surface receptors. A variety of peptides, reported to modulate physiological function in invertebrates, was examined on gill adenylate cyclase. FMRFamide stimulated enzyme activity 7- to 8-fold over basal (Fig. $2 A, \mathrm{EC}_{60}, 1 \mu \mathrm{M}$ ). The heptapeptide YGG-FMRF-amide (TryGly-Gly-Phe-Met-Arg-Phe- $\mathrm{NH}_{2}$ ), which contains the sequences of FMRF-amide as well as of methionine enkephalin (Met-enk), was both less effective (relative efficacy $=0.75$ ) and slightly less potent $\left(\mathrm{EC}_{50}, 3 \mu \mathrm{M}\right)$ than FMRF-amide. Met-enk had no effect on adenylate cyclase activity alone or in the presence of FMRF-amide. Other peptide hormones examined (arginine vasotocin (AVT), vasoactive intestinal polypeptide (VIP), cholecystokinin octapeptide (CCK-8), proctolin, arginine vasopressin (AVP), oxytocin, insulin, glucagon, $\alpha$-melanocyte-stimulating hormone $(\alpha-\mathrm{MSH}))$, as well as the amino acids phenylalanine, methionine, and arginine, were without effect on enzyme activity.

To establish further the specificity of neurohormonal activation of adenylate cyclase, we endeavored to distinguish enzyme stimulation evoked by FMRF-amide from that evoked by DA. The DA receptor blocker chlorpromazine, which signifi-

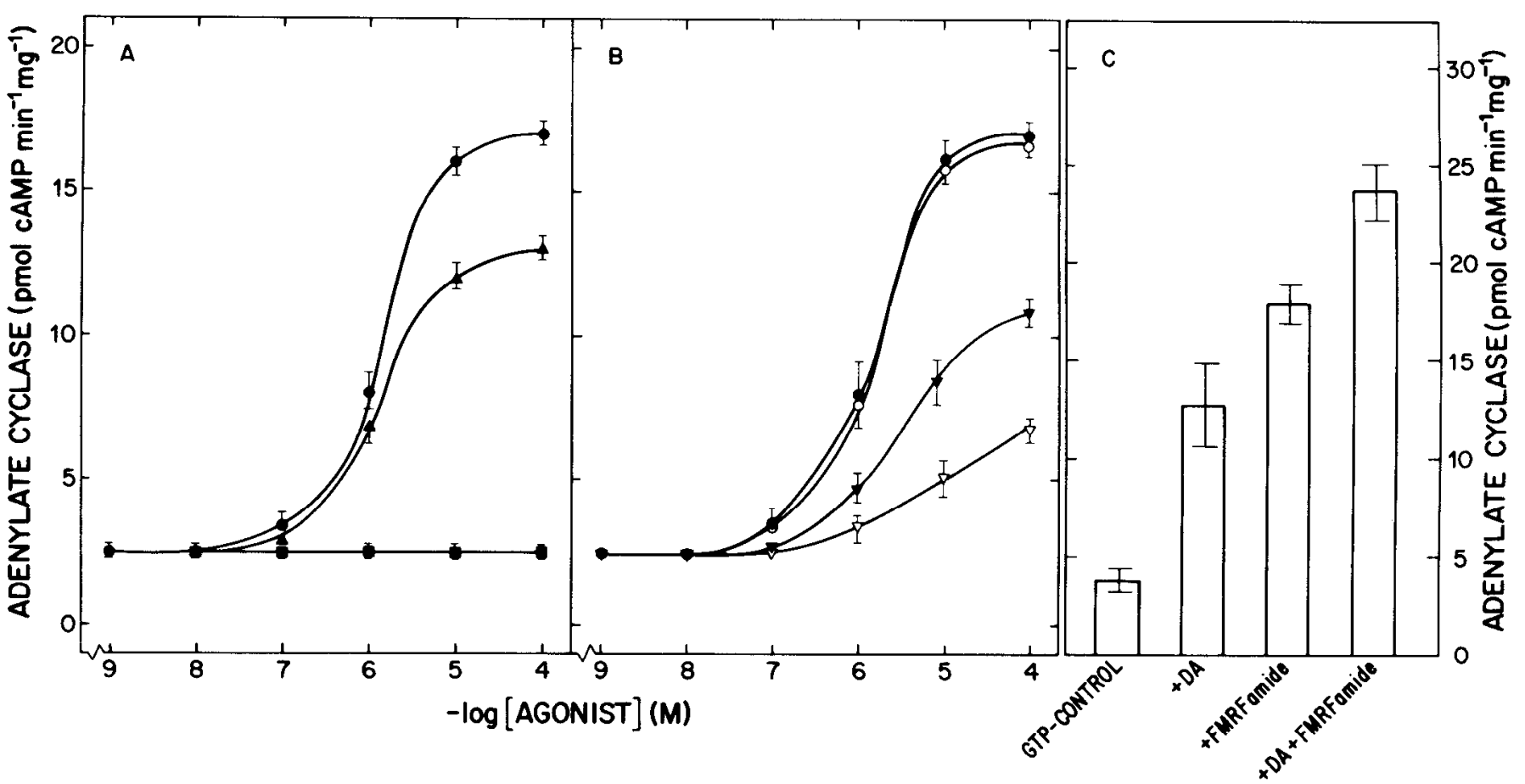

Figure 2. Activation of adenylate cyclase by FMRF-amide and various agents. Data presented are the average of three separate experiments.

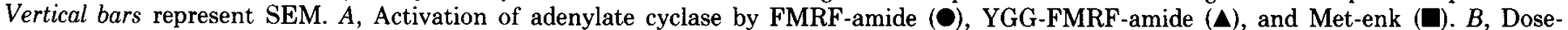
response curve for adenylate cyclase activation by FMRF-amide alone (O) and in the presence of $10 \mu \mathrm{M}$ chlorpromazine $(\mathrm{O})$ and for $\mathrm{DA}$ alone $(\nabla)$ and in the presence of $10 \mu \mathrm{M}$ chlorpromazine $(\nabla)$. $C$, Combined effects of DA and FMRF-amide on adenylate cyclase activity. Activation of adenylate cyclase was determined in the presence of: GTP $(100 \mu \mathrm{M})$ (column 1), GTP (100 $\mu \mathrm{M})$ plus DA (100 $\mu \mathrm{M}($ column 2), GTP (100 $\mu \mathrm{M})$ plus FMRF-amide $(100 \mu \mathrm{M})($ column 3$)$, GTP $(100 \mu \mathrm{M})$ plus DA $(100 \mu \mathrm{M})$ plus FMRF-amide $(100 \mu \mathrm{M})($ column 4$)$. 
cantly diminished DA stimulation, had no effect on stimulation produced by FMRF-amide (Fig. 2B). All DA and serotonin (5$\mathrm{HT}$ ) receptor blockers tested (butaclamol, fluphenazine, methergoline, cyproheptadine, metitepine) were totally ineffective as antagonists to FMRF-amide. Furthermore, stimulation of adenylate cyclase by saturating concentrations of FMRF-amide could be further augmented by DA (Fig. 2C). These findings suggest that adenylate cyclase is stimulated by FMRF-amide and biogenic amines through separate recognition moieties.

cAMP accumulation in gill slices. Kebabian and co-workers (1979) demonstrated that DA and 5-HT augmented cAMP accumulation in gill slices incubated at $30^{\circ} \mathrm{C}$ for $20 \mathrm{~min}$ in the presence of the cAMP phosphodiesterase inhibitor theophylline $(10 \mathrm{mM})$. To establish the ability of FMRF-amide to stimulate cAMP synthesis in intact gills under physiological conditions, tissue slices were examined (as described under "Materials and Methods"). In the absence of a phosphodiesterase inhibitor, FMRF-amide elicited a time-dependent accumulation of cAMP

TABLE I

cAMP accumulation in gill slices

\begin{tabular}{crccc}
\hline & \multicolumn{4}{c}{ cAMP Accumulated $^{a}$} \\
\cline { 2 - 5 } Time & Control & $\begin{array}{c}\text { FMRF-amide } \\
(1 \mu \mathrm{M})\end{array}$ & $\begin{array}{c}\text { Theophylline } \\
(1 \mathrm{mM})\end{array}$ & $\begin{array}{c}\text { Theophylline }(1 \mathrm{mM}) \\
+ \\
\text { FMRF-amide }(1 \mu \mathrm{M})\end{array}$ \\
\hline $\min$ & & & $p m o l / m g$ & \\
0 & 2 & 2 & & \\
1 & 4 & 25 & & 132 \\
2 & 8 & 52 & & \\
5 & 10 & 103 & 11 & \\
10 & 12 & 105 & & \\
\hline
\end{tabular}

${ }^{a}$ Values reported are the means of two experiments performed in duplicate at $25^{\circ} \mathrm{C}$. which was half-maximal at $2 \mathrm{~min}$ and saturated within $5 \mathrm{~min}$ of incubation (Table I). The effects of a phosphodiesterase inhibitor, theophylline $(10 \mathrm{mM})$, on cAMP accumulation were examined. Stimulation by FMRF-amide was potentiated by $30 \%$; control levels were slightly elevated (10 to $12 \%)$. Thus, the neuropeptide that stimulated adenylate cyclase in cell-free preparations was capable of eliciting cAMP accumulation in intact slices of Aplysia gill.

Contractile responses of the isolated gill to peptides and cAMP. As FMRF-amide had been determined to be a potent agonist to both adenylate cyclase stimulation and cAMP accumulation, possible effects of this agent on gill movements were examined. The effects of intravascular FMRF-amide on gill contraction are illustrated in Figure 3. At threshold levels (3 nM), 5 to 7 min of constant perfusion resulted in phasic contractions of varying intensity that were readily reversible (Fig. $3 A$ ). Movements of the efferent trunklets and pinnule muscle resembled those evoked by DA (Ruben et al., 1979), yet FMRF-amide elicited more intense contractions of the afferent vein. The response to FMRF-amide at suprathreshold levels (Fig. 3B) was rapid in onset, and both the force of contraction and the duration of the contractile response were dose-dependent. At saturating concentrations (1 $\mu \mathrm{M})$, FMRF-amide evoked the maximum contractile withdrawal of the gill. Other peptides examined, i.e., AVT, Met-enk, VIP, CCK-8, and proctolin, were unable to elicit gill contractions. YGG-FMRF-amide evoked gill contractions with a lower potency than that of FMRFamide (threshold, 10 to $100 \mathrm{nM}$ ). FMRF-amide-induced contractions were mimicked by perfusion of parachlorophenylthiocAMP (pCPTcAMP) (Fig. $3 A$ ) or 8 benzylthio-cAMP and were elicited in all preparations examined. Membrane-permeable analogues of cGMP were ineffective.

Although histochemical analyses (Peretz and Estes, 1974) have demonstrated the existence of DA and 5-HT in neurons in the gill, there has been no evidence for FMRF-amide-con-

A.

FMRFamide (3nM)

PCPT CAMP $(32 \mu \mathrm{M})$
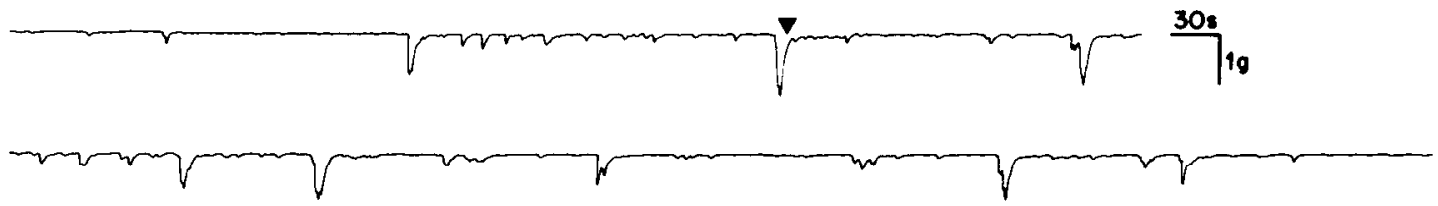

B.

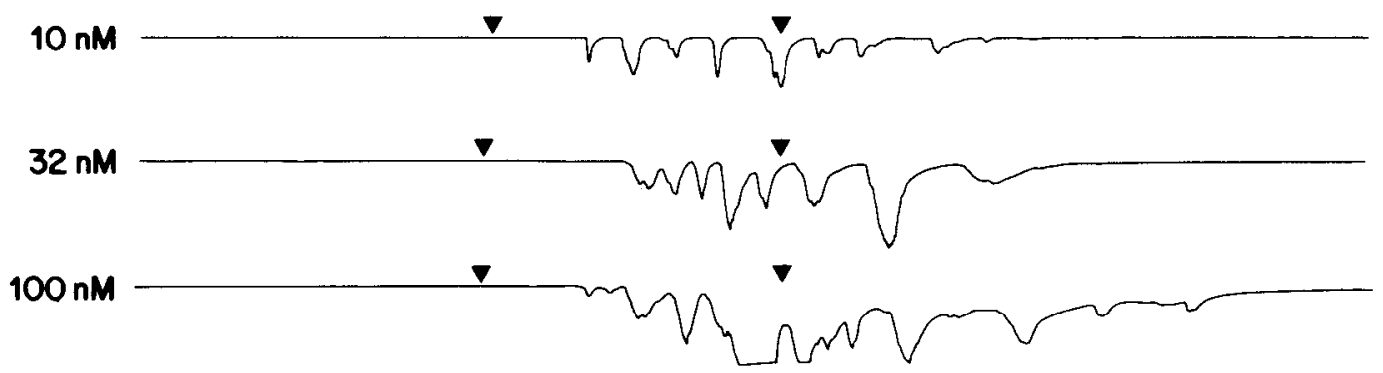

Figure 3. Contractile responses of the isolated Aplysia gill to $\mathrm{FMRF}$-amide and cAMP. After each treatment, at least 60 min were allowed between washout and administration of the subsequent test substance. $A$, Top trace, Phasic contractions elicited after 5 to 7 min of a threshold ( $3 \mathrm{nM})$ dose of FMRF-amide. Gills were quiescent prior to drug application. The arrowhead indicates washout. A, Bottom trace, Contractions evoked after 5 to $7 \mathrm{~min}$ of a threshold $(32 \mu \mathrm{M})$ dose of pCPTcAMP, in the same experiment. $B$, Dose dependence of FMRF-amide-evoked contractions. Arrowheads denote administration and washout of $10 \mathrm{nM}$ (top), $32 \mathrm{nM}$ (middle), and $100 \mathrm{nM}$ (bottom) FMRF-amide, in a single experiment. 

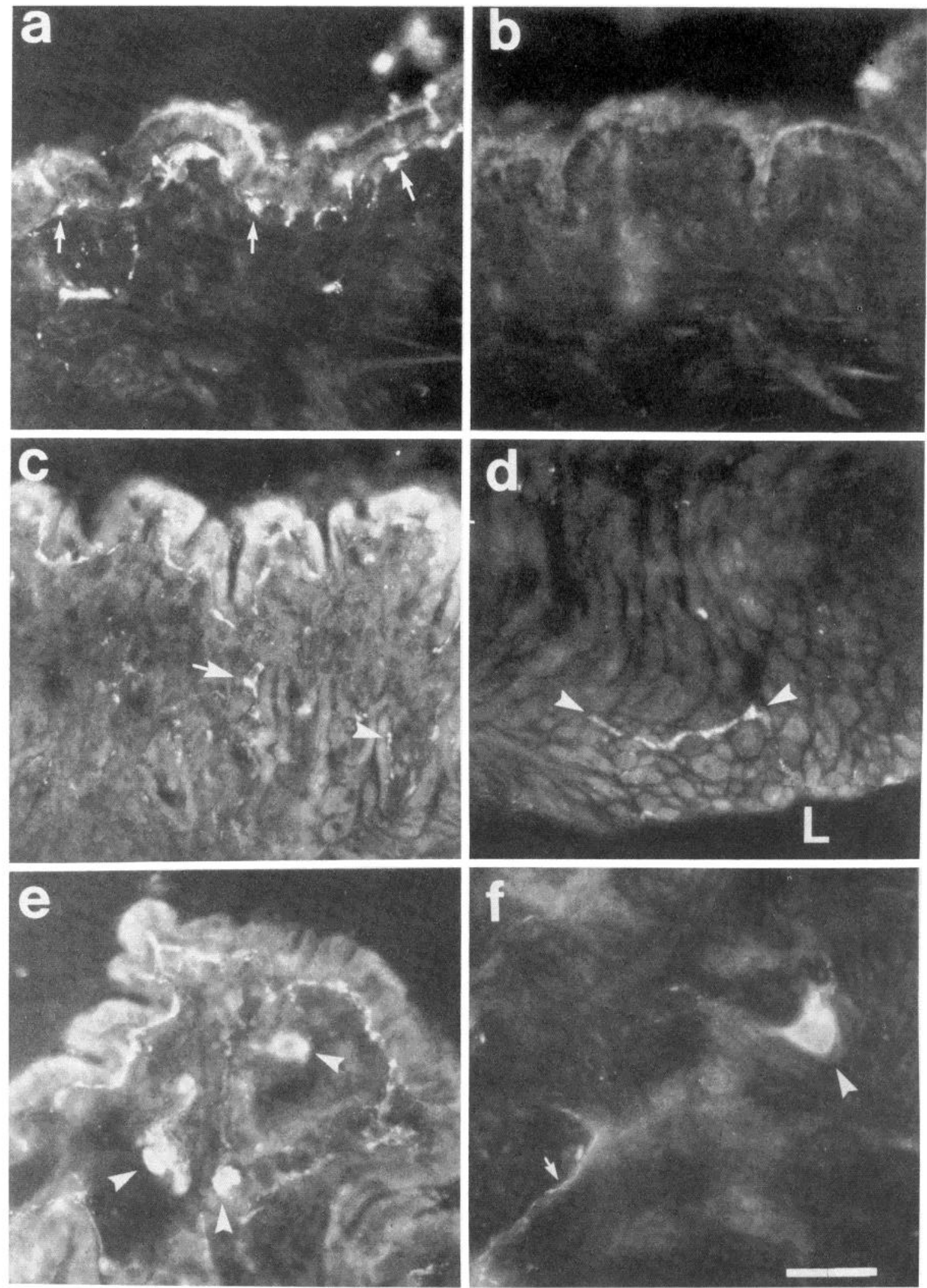

Figure 4. Immunofluorescent localization of FLI in Aplysia gill. Pieces of gill were fixed with $4 \%$ paraformaldehyde in $0.05 \mathrm{M}$ phosphate buffer, $\mathrm{pH} 7.4$, containing $3 \%$ sucrose, for $2 \mathrm{hr}$ at $20^{\circ} \mathrm{C}$. They were then filtrated gradually with $30 \%$ sucrose in buffer; cryostat sections were cut at $15 \mu \mathrm{m}$ and thaw-mounted onto gelatin-coated slides. Sections were incubated overnight at $20^{\circ} \mathrm{C}$ with primary antiserum (L-135) diluted $1: 100$ in phosphate buffer, $\mathrm{pH} 7.4$, containing $0.1 \%$ Triton X-100. After washing they were treated in fluorescein isothiocyanate-conjugated goat antirabbit gamma globulin (Cappell) diluted 1:50 in the same vehicle, washed again, and mounted in glycerol. Sections were viewed and photographed with a Zeiss epifluorescence attachment. Magnification marker $=50 \mu \mathrm{m}(a$ to $d)$ or $35 \mu \mathrm{m}(e$ and $f)$. $a$, FLI in dense plexus under base of pigmented respiratory epithelium (arrows). $b$, Absence of FLI in section of gill treated with preabsorbed (control) antiserum. $c$, FLI in subepithelial plexus, as in $a$, cell body (arrow), and scattered among muscle fibers (arrowhead). $d$, FLI in nerve fibers among muscle lining the afferent vein. $L$, lumen. $e$, FLI in several nerve cells (arrowheads) in connective tissue beneath unpigmented respiratory epithelium. $f$, FLI in nerve fiber (arrow) and cell body (arrowhead) of gill muscle. 
taining cells. FMRF-amide-like immunoreactivity (FLI) was examined in gills which were fixed with paraformaldehyde, cryosectioned, reacted with antiserum to FMRF-amide, and stained with fluorescein-labeled second antibody. Preabsorption of primary antiserum with $100 \mu \mathrm{M}$ FMRF-amide overnight served as a control. Specific FLI was observed in a dense fiber plexus just beneath the respiratory epithelium, in fine fibers sparsely distributed in the muscle layers, and in large cell bodies scattered in the muscle or connective tissue (Fig. 4).

\section{Discussion}

It has been suggested that neuropeptides might serve as longduration mimics of fast-acting transmitter substances. Following its discovery in ganglia isolated from $M$. nimbosa (Price and Greenberg, 1977), FMRF-amide mimicked the effects of 5HT as a cardioexcitatory agent of Macrocallista and Mercenaria hearts (Price and Greenberg, 1980) via a pharmacologically distinct receptor. FMRF-amide was more potent than 5-HT in stimulating cardioexcitation, cAMP accumulation, and adenylate cyclase activity (Higgins et al., 1978). These findings suggest that a neuropeptide and a biogenic amine transmitter act on separate, specific receptors to trigger a common intracellular mechanism, resulting in the same whole organ response.

FMRF-amide or a related peptide is present within neurons of the peripheral nerve plexus of the gill (Fig. 4). These findings suggest that FMRF-amide may be released by neuronal excitation to act on muscle fibers. In the gill particulate preparation, FMRF-amide stimulated adenylate cyclase $\left(\mathrm{EC}_{50}, \mathbf{1} \mu \mathrm{M}\right)$, whereas Met-enk had no effect on basal or hormone-sensitive enzyme activity (Fig. 2A). FMRF-amide was 10 -fold more potent than $\mathrm{DA}\left(\mathrm{EC}_{50}, 10 \mu \mathrm{M}\right.$, Fig. $\left.2 B\right)$ and activated adenylate cyclase at receptors distinct from those of DA (Fig. $2, B$ and $C$ ) and 5-HT. Similarly, FMRF-amide was more potent and effective than DA in eliciting cAMP accumulation in gill slices, yet both neurohormones exhibited a similar time course of activa-

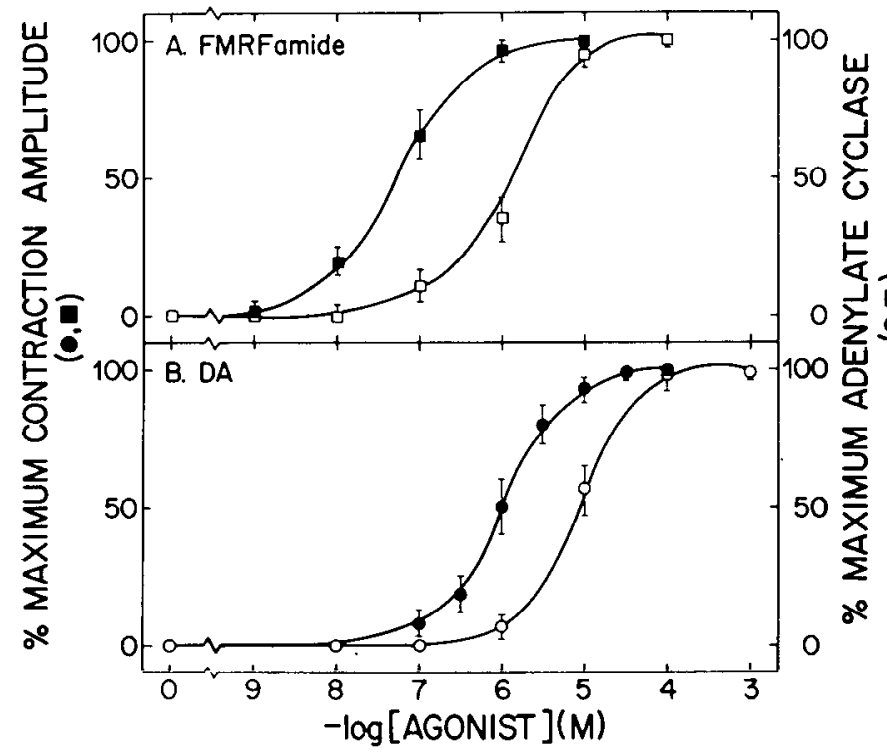

Figure 5. Comparison of dose-response curves for neurohormoneelicited contractions and stimulation of adenylate cyclase by FMRFamide and DA. Dose-response curves for percentage of maximum contraction amplitude (solid symbols) and percentage of maximum adenylate cyclase activation (open symbols) were determined with varying concentrations of FMRF-amide $(A)$ and DA $(B)$. Each concentration was examined in at least three separate experiments with different preparations. Vertical bars represent SEM. tion. Furthermore, when infused through the gill, FMRF-amide $\left(\mathrm{EC}_{50}, 0.1 \mu \mathrm{M}\right)$ was 10 -fold more potent than DA $\left(\mathrm{EC}_{50}, 1 \mu \mathrm{M}\right)$ in eliciting phasic contractions (Fig. 5). FMRF-amide-induced contractions were more intense than those of $\mathrm{DA}$, with more pronounced movements of the afferent vein. This suggests a greater population of FMRF-amide (or of a related peptide) receptors in the afferent vein, accounting for greater efficacy in cAMP accumulation and contraction amplitude.

In catch muscle, FMRF-amide stimulated tonic contractions (similar to $\mathrm{ACh}$ ) without affecting tissue levels of cAMP (Painter, 1982). In Aplysia, it has been demonstrated that FMRF-amide inhibited spontaneous and $\mathrm{ACh}$-induced contractions of the anterior gizzard without affecting adenylate cyclase (Austin et al., 1983). In some molluscan hearts, FMRF-amide elicited cardioexcitation (Higgins et al., 1978; Painter and Greenberg, 1982) or cardioinhibition (Painter, 1982) accompanied by increases in tissue levels of cAMP (similar to $5-\mathrm{H}^{\top} \mathrm{T}$ ). Our findings of FMRF-amide stimulation of phasic gill contractions, with increases in cAMP levels, suggest a mechanism that differs from those previously reported.

Swann and co-workers (1978) have demonstrated that stimulation of discrete central neurons as well as DA perfusion through the gill results in peristaltic pumping movements. These gill-pumping movements appear to augment the circulatory system of Alpysia by forcing hemolymph through the gill via the efferent vessel to the heart. Similar to its action on other molluscan hearts and on catch muscle, FMRF-amide or a related peptide may represent a long-duration mimic of DA effects on gill muscle. Along with studies of Aplysia brasiliana (Morris et al., 1982), our findings suggest that FMRF-amidelike peptides play an important role in modulating the behavior of Aplysia peripheral organs.

\section{Reference}

Austin, T., S. Weiss, and K. Lukowiak (1983) FMRFamide effects on spontaneous and induced contractions of the anterior gizzard in Aplysia. Can. J. Physiol. Pharmacol. 61: 949-953.

Brown, B. L., J. D. M. Albano, R. P. Ekins, A. M. Sgherzic, and W. Tampion (1971) $\Lambda$ simple and sensitive saturation assay method for the measurement of adenosine $-3^{\prime}: 5^{\prime}$-cyclic monophosphate. Biochem. J. 121: 561-562.

Cottrell, G. A. (1982) FMRFamide neuropeptides simultaneously increase and decrease $\mathrm{K}^{+}$currents in an identified neurone. Nature 296: $87-89$.

Grayton, K. J. (1982) Mammalian neuronal actions of FMRFamide and the structurally related opioid Met-enkephalin- $-\mathrm{Arg}^{6}-\mathrm{Phe}^{7} . \mathrm{Na}-$ ture 298: 275-276.

Higgins, W. J., D. A. Price, and M. J. Greenberg (1978) FMRFamide increases the adenylate cyclase activity and cyclic AMP level of molluscan heart. Eur. J. Pharmacol. 48: 425-430.

Kebabian, P. R., J. W. Kebabian, and D. O. Carpenter (1979) Regulation of cyclic AMP in heart and gill by the putative neurotransmitters dopamine and serotonin. Life Sci. 24: 1757-1764.

Lowry, D. H., N. J. Rosebrough, A. J. Farr, and R. J. Randal (1951) Protein measurement with the Folin phenol reagent. J. Biol. Chem. 193: $265-275$

Lukowiak, K., and B. Peretz (1977) The interaction between the central and peripheral nervous systems in the mediation of gill withdrawal reflex behavior in Aplysia. J. Comp. Physiol. 117: 219-244.

Lukowiak, K., J. A. Thornhill, and J. P. Edstrom (1982) Methionine enkephalin increases CNS suppressive control exerted over gill reflex behavior and associated neural activity in Aplysia. Reg. Peptides 3: 303-312.

Moore, G. J., J. A. Thornhill, V. Gill, K. Lederis, and K. Lukowiak (1981) An arginine vasotocin-like neuropeptide is present in the nervous system of the marine mollusc Aplysia californica. Brain Res. 206: $213-218$

Morris, H. R., M. Panico, A. Karplus, P. E. Lloyd, and B. Rinicker (1982) Elucidation by FAB-MS of the structure of a new cardioactive peptide from Aplysia. Nature 300: 643-645.

Painter, S. D. (1982) FMRFamide inhibition of a molluscan heart is 
accompanied by increases in cAMP. Neuropeptides 3: 19-27.

Painter, S. D., and M. J. Greenberg (1982) A survey of the responses of bivalve hearts to the molluscan neuropeptide FMRFamide and to 5-hydroxytryptamine. Biol. Bull. 162: 311-332.

Peretz, B., and J. Estes (1974) Histology and histochemistry of the peripheral neural plexus in the Aplysia gill. J. Neurobiol. 5: 3-19.

Price, D. A., and M. J. Greenberg (1977) Structure of a molluscan cardioexcitatory neuropeptide. Science 197: 670-671.

Price, D. A., and M. J. Greenberg (1980) The pharmacology of the molluscan cardioexcitatory neuropeptide FMRFamide. Gen. Pharmacol. 11: 237-241.

Ruben, P., and K. Lukowiak (1979) Dopamine modulation of gill reflex behavior in Aplysia. Can. J. Physiol. Pharmacol. 57: 329-332.

Ruben, P. C., J. W. Swann, and D. O. Carpenter (1979) Neurotransmitter receptors on gill muscle fibers and the gill peripheral nerve plexus in Aplysia. Can. J. Physiol. Pharmacol. 57: 1088-1097.

Salomon, Y., C. Londos, and M. Rodbell (1974) A highly sensitive adenylate cyclase assay. Anal. Biochem. 58: 541-548.

Swann, J. W., C. N. Sinback, and D. O. Carpenter (1978) Dopamineinduced contractions and modulation of neuromuscular transmission in Aplysia. Brain Res. 157: 167-172.

Voshart, K., and K. Lukowiak (1982) FMRFamide increases CNS controlled gill reflex behaviors and associated neural activity in Aplysia. Soc. Neurosci. Abstr. 8: 99.1. 